\title{
Epicardial adipose tissue thickness and its association with adiponectin in metabolic syndrome patients from Mérida, Venezuela
}

\author{
Associação entre a espessura do tecido adiposo \\ epicárdico e a adiponectina em pacientes com \\ síndrome metabólica em Mérida, Venezuela
}

Marcos M. Lima-Martínez', Gabriel López-Mendez², Rodolfo Odreman ${ }^{2}$, José H. Donis ${ }^{2}$, Mariela Paoli ${ }^{3}$

1 Division of Medical Physiology, Department of Physiological Sciences, University of Oriente, Ciudad Bolívar, Venezuela ${ }^{2}$ Cardiology Research Institute, University Hospital of Los Andes, Mérida, Venezuela ${ }^{3}$ Endocrinology Unit, University Hospital of Los Andes, Mérida, Venezuela

\author{
Correspondence to: \\ Marcos M. Lima-Martínez \\ Avenida Tachira, \\ Conjunto Residencial Monacaya, \\ Town House 12 \\ Ciudad Bolívar, \\ Estado Bolívar, Venezuela \\ marcoslimamedical@hotmail.com \\ Received on Jul/16/2013 \\ Accepted on Jan/24/2014 \\ DOI: 10.1590/0004-2730000002888
}

\begin{abstract}
Objective: To study the relationship between epicardial adipose tissue (EAT) thickness and plasma levels of adiponectin in Venezuelan patients. Subjects and methods: Thirty-one patients diagnosed with metabolic syndrome (study group) and 27 controls were selected and tested for glycemia, lipids, and adiponectin. EAT thickness, ejection fraction, diastolic function, left ventricular mass (LVM), and left atrial volume (LAV) were determined by transthoracic echocardiography. Results: EAT thickness was greater in metabolic syndrome patients $(5.69 \pm 1.12$ vs. $3.52 \pm 0.80 \mathrm{~mm} ; \mathrm{p}=0.0001)$, correlating positively with body mass index (BMI) $(r=0.661 ; p=$ $0.0001)$; waist circumference (WC) $(r=0.664 ; p=0.0001)$; systolic (SBP) $(r=0.607 ; p=0.0001)$, and diastolic blood pressure (DBP) $(r=0.447 ; p=0.0001)$; insulin $(r=0.505 ; p=0.0001) ; \mathrm{Tg} / \mathrm{HDL}-\mathrm{C}$ ratio $(r=0.447 ; p=0.0001)$, non-HDL-C $(r=0.353 ; p=0.007) ; L A V(r=0.432 ; p=0.001)$, and LVM $(r=0.469 ; p=0.0001)$. EAT thickness correlated negatively with adiponectin $(r=-0.499 ; p=$ 0.0001). Conclusion: A significant association exists between EAT thickness and both metabolic syndrome components and adiponectin concentration, a link that might be used as a biomarker for this disease. Arq Bras Endocrinol Metab. 2014;58(4):352-61
\end{abstract}

Keywords

Epicardial adipose tissue; epicardial fat; metabolic syndrome; adiponectin; Hispanics

\section{RESUMO}

Objetivo: Estudar a relação entre a espessura do tecido adiposo epicárdico (TAE) e os níveis plasmáticos de adiponectina em pacientes venezuelanos. Sujeitos e métodos: Foram selecionados 31 pacientes com diagnóstico de síndrome metabólica (SM) (grupo de estudo) e 27 controles. Foram medidos a glicose, os lipídios e a adiponectina. Foram determinados a espessura doTAE, a fração de ejeção, a função diastólica, a massa ventricular esquerda (MVE) e o volume atrial esquerdo (VAl) pela ecocardiografia transtorácica. Resultados: A espessura do TAE foi maior em pacientes com SM $(5,69 \pm 1,12$ contra 3,52 $\pm 0,80 \mathrm{~mm} ; \mathrm{p}=0,0001)$ com uma correlação positiva com o índice de massa corporal (IMC) $(r=0,661 ; p=0,0001)$, circunferência da cintura (CC) $(r=0,664 ; p=0,0001)$, pressão arterial sistólica (PAS) $(r=0,607 ; p=0,0001)$, diastólica (PAD) $(r=0,447 ; p=0,0001)$, insulina $(r=0,505 ; p=0,0001)$, com a relaçãoTG/HDL-C ( $r$ $=0,447 ; p=0,0001)$, com o colesterol HDL $(r=0,353 ; p=0,007)$, VAI $(r=0,432 ; p=0,001)$ e MVI $(r=0,469 ; p=0,0001)$. A espessura doTAE se correlacionou negativamente com a adiponectina $(r=-0,499 ; p=0,0001)$. Conclusão: Existe uma relação significativa entre a espessura doTAE, os componentes do SM e a concentração plasmática de adiponectina, o que poderia ser utilizado como um biomarcador para essa doença. Arq Bras Endocrinol Metab. 2014;58(4):352-61

\section{Descritores}

Tecido adiposo epicárdico; gordura epicárdica; síndrome metabólica; adiponectina; hispânicos 


\section{INTRODUCTION}

$\mathrm{T}$ he recognition of the adipocyte as a highly complex endocrine organ, capable of secreting a series of bioactive molecules, collectively known as adipocytokines, has triggered great interest in the adipose tissue, and particularly visceral adiposity (1). Increase in visceral adiposity is associated with high cardiometabolic risk, a characteristic that defines the metabolic syndrome. Despite the current focus on intra-abdominal visceral adiposity, some extra-abdominal fat deposits, such as epicardial fat, are now acknowledged as markers of cardiovascular risk (2).

Epicardial adipose tissue (EAT) or epicardial fat develops from brown adipose tissue during embryogenesis. At adult age, it tends to settle between the atrioventricular or interventricular grooves, extending to the apex (3). It has been proposed that this tissue could act as a physiolgical buffer that protects the heart against cardiolipotoxicity generated by free fatty acids (3). Adequately functioning epicardial adipocytes can secrete a number of adipocytokines, one of which is adiponectin, a 247-amino acid peptide with insulin-sensitizing, anti-atherogenic, and anti-inflammatory properties that offers multiple benefits in diseases such as atherosclerosis, ischemic cardiopathy, and arterial hypertension (4). It is well known that high-sensitivity C-reactive protein (hs-CRP) is a risk marker for coronary artery disease, and during the last decade, Ouchi and cols. (5) have described a strong negative association between adiponectin and hs-CRP, both in plasma and in the adipose tissue of patients with atherosclerotic coronary disease.

Some authors have found metabolic syndrome patients to have a thicker layer of epicardial fat $(6,7)$. Torres and cols. (8) demonstrated, in their unprecedented Ciudad Bolivar study, in Venezuela, that among Hispanics, EAT thickness is greater in metabolic syndrome patients than in control subjects. However, until this study, no other has established a relationship between EAT thickness and plasma levels of adiponectin in Hispanic patients.

\section{SUBJECTS AND METHODS}

\section{Design and subjects of the study}

An observational, analytical, cross-sectional study was designed. The selection of subjects was carried out in accordance with the International Diabetes Federa- tion (IDF) guidelines for the diagnosis of metabolic syndrome (9). A sample of 31 (19 female, 12 male) metabolic syndrome subjects aged 20 to 60 years old, with inclusion of at least three of the following criteria: 1. Waist circumference (WC): $\geq 90 \mathrm{~cm}$ in men; $\geq 80 \mathrm{~cm}$ in women; 2 . Triglyceride plasma levels: $\geq 150 \mathrm{mg} / \mathrm{dL}$; 3. HDL-C: $<40 \mathrm{mg} / \mathrm{dL}$ in $\mathrm{men} ;<50 \mathrm{mg} / \mathrm{dL}$ in women; 4. Systolic blood pressure (SBP): $\geq 130 \mathrm{mmHg}$ and/or diastolic blood pressure (DBP) $\geq 85 \mathrm{mmHg} ; 5$. Fasting blood glucose: $\geq 100 \mathrm{mg} / \mathrm{dL}$.

These subjects were compared with 27 age- and sex-matched controls without metabolic syndrome. According to the Helsinki Declaration, all subjects gave informed consent to participate in the study. The study did not include subjects with primary hyperlipidemia; endocrinopathies, such as diabetes mellitus, hypothyroidism, Cushing syndrome, or acromegaly; or any other comorbidity or drug (glucocorticoids, anticonvulsants, or hypolipidemic agents) that would be able to affect metabolic variables.

\section{Clinical evaluation}

A brief medical history was taken to gather demographic data, such as age, sex, and associated personal and family background. Weight and height were measured with subjects wearing only their underwear. BMI was calculated as weight in kilograms divided by height in meters squared. Waist circumference (WC) was measured midway between the underside of the lowest rib and the iliac crests, in centimeters, with subjects standing. Blood pressure was taken using the auscultation method with a conventional mercury sphygmomanometer on the right arm.

\section{Biochemical variables}

A blood sample was taken from the antecubital vein after subjects had fasted for no less than eight hours. Glycemia and blood lipids (total cholesterol, triglycerides, and HDL-C) were analyzed in a Hitachi $911^{\circledR}$ autoanalyzer with reagents from CienVar Laboratories, using enzymatic methods.

Low-density lipoprotein cholesterol (LDL-C) was estimated using the Friedewald Equation, where LDL-C $=$ Total cholesterol $-[$ HDL-C $+($ Triglycerides/5)]. Non-high density lipoprotein cholesterol (Non-HDL-C) was obtained by subtracting HDL-C from total cholesterol, and the triglyceride to HDL-C ratio ( $\mathrm{Tg} / \mathrm{HDL}-\mathrm{C}$ ratio) was determined by dividing triglyceride plasma concentration by HDL-C. 
Plasma levels of adiponectin were ascertained with an ELISA kit (DRG International Inc, New Jersey, USA), using the immunoenzymatic method. hs-CRP was determined by a chemoluminescence immunoassay using commercial kits from Siemens Healthcare Diagnostics, California, USA.

\section{Echocardiografic variables}

Standard transthoracic two-dimensional echocardiography was performed with a Vivid 7 Dimension Ultrasound scanner (GE Healthcare, Wisconsin, USA) with patients in left lateral recumbent position. Echocardiograms were interpreted by a cardiologist-echocardiographer in order to guarantee the validity of the studies. The echocardiographer was blind to the condition of the subjects.

Echocardiographically, EAT was observed as the echolucent space between the outer wall of the myocardium and the visceral pericardium. This thickness was measured perpendicularly on the free wall of the right ventricle at end-systole in three cardiac cycles, using both long and short-axis parasternal views (10).

Left ventricular mass (LVM) was determined similarly in the parasternal long-axis view, using the anatomically validated formula of Devereux and cols. (11), and subsequently indexed to the patient's body surface area (BSA). Left atrial volume (LAV) was measured using both apical two- and four-chamber echo views, subsequently averaged to the patient's BSA.

The left ventricle diastolic function (LVDF) was determined using transmitral flow and tissue Doppler echocardiography. The left ventricle ejection fraction (LVEF) was obtained by subtracting the end systolic volume from the end diastolic volume, and dividing the result by the end diastolic volume (x 100).

\section{Statistical analysis}

All continuous variables are presented as means \pm standard deviations, and categorical variables, as numbers and percentages. The chi-square test was used to determine any significant sex-related differences between the groups. Student's t-test for independent data assessed the mean difference of normally-distributed continuous variables between subjects with and without metabolic syndrome, while Mann-Whitney U test was used for non-normally distributed variables (SBP, DBP, insulin, hs-CRP, and LVEF). To measure variable dependency in metabolic syndrome, and to determine which vari- able was the most influential, Pearson or Spearman correlation, according the distribution of the variable, and both uni- and multi-variate linear regression analyses were conducted using EAT as the dependent variable. In addition, uni- and multivariate logistic regression analyses with metabolic syndrome as the dependent variable were done in order to determine the variable that best defined the disorder. Finally, univariate and multivariate linear regression analyses were undertaken with SBP, Tg/HDL-C ratio, non-HDL-C, and adiponectin plasma concentrations as dependent variables, and body mass index and EAT thickness as independent variables to determine if epicardial fat was related to these metabolic variables independent of the degree of obesity. SPSS 15.0 for Windows was used in the statistical analysis, with $\mathrm{p}$ value $\leq 0.05$ considered statistically significant.

\section{RESULTS}

Table 1 presents the anthropometric and clinical data of the participants. The control group comprised 27 subjects -19 females and 8 males - with an average age of $38.67 \pm 9.80$ years, and a mean BMI of $24.32 \pm 3.48$ $\mathrm{kg} / \mathrm{m}^{2}$. The study group comprised 31 patients -19 females and 12 males - with an average age of 39.06 \pm 10.00 years, and mean BMI of $34.26 \pm 6.31 \mathrm{~kg} / \mathrm{m}^{2}$. There were no statistically significant differences in age, sex, height, or pathological familial histories between the two groups. Weight, BMI, WC, SBP, and DBP were significantly higher $(\mathrm{p}=0.0001)$ in the study group, which had a greater incidence $(\mathrm{p}=0.0001)$ of personal diseases - obesity, dyslipidemia, high blood pressure, and tobacco use $(67.7 \%$ vs. $3.7 ; 48.4 \%$ vs. $11.1 \% ; 41.9 \%$ vs. $0 \%$; and $6.5 \%$ vs. $0 \%$, respectively) being the most frequent. Ten of the 13 patients with a history of high blood pressure were on monotherapy (six on angiotensin-converting enzyme inhibitors, and four on angiotensin II receptor blockers) and three on combined therapy (two on angiotensin II receptor blockers and calcium blockers; and one on angiotensinconverting enzyme inhibitor plus a diuretic).

As expected, when comparing the biochemical variables between participants (Table 2), the study group revealed significantly higher plasma levels of fasting blood glucose $(p=0.005)$, basal insulin $(p=0.0001)$, non-HDL-C $(\mathrm{p}=0.002)$, triglycerides $(\mathrm{p}=0.0001)$, $\mathrm{Tg} / \mathrm{HDL}-\mathrm{C}$ ratio $(\mathrm{p}=0.0001)$, and hs-CRP $(\mathrm{p}=$ $0.0001)$, as well as lower plasma levels of HDL-C ( $\mathrm{p}=$ $0.001)$ and adiponectin $(\mathrm{p}=0.0001)$ than the control 
group. No statistically significant differences between the groups were observed in the plasma concentrations of total cholesterol $(\mathrm{p}=0.051)$ and LDL-C $(\mathrm{p}=0.110)$.

Table 3 presents the echocardiographic data of the participants. The thickness of epicardial fat $(\mathrm{p}=0.0001)$ and $\operatorname{LVM}(\mathrm{p}=0.019)$, as well as $\operatorname{LAV}(\mathrm{p}=0.021)$ were significantly greater in the study group. No significant differences were observed in either LVEF $(\mathrm{p}=0.503)$ or the left ventricle diastolic dysfunction (LVDD) $(\mathrm{p}=$ 0.068 ) between the groups.

Table 1. Anthropometric and clinical data of the participants

\begin{tabular}{lccc}
\hline Variables & $\begin{array}{c}\text { Control group } \\
\mathbf{N}=\mathbf{2 7}\end{array}$ & $\begin{array}{c}\text { Study group } \\
\mathbf{N}=\mathbf{3 1}\end{array}$ & p value \\
\hline Age (years) & $38.67 \pm 9.80$ & $39.06 \pm 10.00$ & 0.879 \\
Sex: female/male & $19(70.4) / 8(29.6)$ & $19(61.3) / 12(38.7)$ & 0.468 \\
Weight $(\mathrm{kg})$ & $64.60 \pm 11.96$ & $90.86 \pm 19.84$ & 0.0001 \\
Positive personal background & $3(11.1)$ & $28(90.3)$ & 0.0001 \\
Positive family background & $22(81.5)$ & $29(93.5)$ & 0.159 \\
Height $(\mathrm{m})$ & $1.63 \pm 0.09$ & $1.62 \pm 0.09$ & 0.956 \\
$\mathrm{BM}^{\mathrm{a}}\left(\mathrm{kg} / \mathrm{m}^{2}\right)$ & $24.32 \pm 3.48$ & $34.26 \pm 6.31$ & 0.0001 \\
WC $^{b}(\mathrm{~cm})$ & $77.16 \pm 10.32$ & $102.29 \pm 14.32$ & 0.0001 \\
$\mathrm{SBP}^{\mathrm{c}}(\mathrm{mmHg})$ & $111.48 \pm 8.18$ & $135.48 \pm 14.28$ & 0.0001 \\
$\mathrm{DBP}^{\mathrm{d}}(\mathrm{mmHg})$ & $70.37 \pm 7.96$ & $82.58 \pm 9.30$ & 0.0001 \\
\hline
\end{tabular}

Continuous variables are presented as $\mathrm{X} \pm \mathrm{SD}$, and the categorical variables as $\mathrm{N}(\%)$.

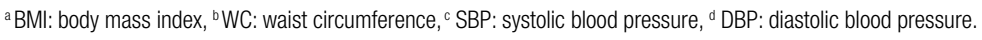

Table 2. Biochemical variables of the participants

\begin{tabular}{|c|c|c|c|}
\hline Variables & $\begin{array}{c}\text { Control group } \\
n=27\end{array}$ & $\begin{array}{l}\text { Study group } \\
\quad \mathrm{n}=\mathbf{3 1}\end{array}$ & $p$ value \\
\hline Glycemia (mg/dL) & $90.11 \pm 8.82$ & $98.16 \pm 12.03$ & 0.005 \\
\hline Insulin (mU/mL) & $2.10 \pm 0.54$ & $6.08 \pm 5.22$ & 0.0001 \\
\hline Total cholesterol (mg/dL) & $172.67 \pm 22.51$ & $190.52 \pm 43.29$ & 0.051 \\
\hline $\mathrm{HDL}-\mathrm{C}^{\mathrm{a}}(\mathrm{mg} / \mathrm{dL})$ & $56.11 \pm 10.78$ & $46.68 \pm 8.73$ & 0.001 \\
\hline $\mathrm{LDL}-\mathrm{C}^{\mathrm{b}}(\mathrm{mg} / \mathrm{dL})$ & $93.68 \pm 17.98$ & $105.77 \pm 36.55$ & 0.110 \\
\hline Non-HDL-C (mg/dL) & $116.55 \pm 21.57$ & $143.84 \pm 41.07$ & 0.002 \\
\hline Triglycerides (mg/dL) & $112.15 \pm 52.16$ & $204.26 \pm 94.43$ & 0.0001 \\
\hline Tg/HDL-C ratio & $2.10 \pm 1.15$ & $4.52 \pm 2.37$ & 0.0001 \\
\hline Adiponectin (ng/mL) & $14.95 \pm 3.87$ & $11.20 \pm 2.65$ & 0.0001 \\
\hline hs-CRPc (mg/L) & $2.20 \pm 2.54$ & $6.59 \pm 6.26$ & 0.0001 \\
\hline
\end{tabular}

Continuous variables are presented as $\mathrm{X} \pm \mathrm{SD}$.

${ }^{a}$ HDL-C: high-density lipoprotein cholesterol; ' LDL-C: low-density lipoprotein cholesterol; ' $\mathrm{hs-CRP:} \mathrm{high-sensitivity} \mathrm{C-reactive} \mathrm{protein.}$

Table 3. Echocardiographic data of the participants

\begin{tabular}{lccc}
\hline Variables & $\begin{array}{c}\text { Control group } \\
\mathbf{n = 2 7}\end{array}$ & $\begin{array}{c}\text { Study group } \\
\mathbf{n = 3 1}\end{array}$ & p value \\
\hline Epicardial fat $(\mathrm{mm})$ & $3.52 \pm 0.80$ & $5.69 \pm 1.12$ & 0.0001 \\
Left ventricular mass $\left(\mathrm{g} / \mathrm{m}^{2}\right)$ & $53.01 \pm 8.40$ & $60.28 \pm 14.00$ & 0.019 \\
Ejection fraction $(\%)$ & $65.15 \pm 3.17$ & $64.55 \pm 3.60$ & 0.503 \\
Left atrial volume $\left(\mathrm{mL} / \mathrm{m}^{2}\right)$ & $19.26 \pm 4.03$ & $22.15 \pm 5.19$ & 0.021 \\
Left ventricle diastolic dysfunction & $6(19.4)$ & $1(3.7)$ & 0.068 \\
\hline
\end{tabular}

Continuous variables are presented as $\mathrm{X} \pm \mathrm{SD}$, and the categorical variables as $\mathrm{N}(\%)$. 
The correlation analysis revealed that epicardial fat thickness (measured in $\mathrm{mm}$ ) showed a statistically significant positive correlation with BMI $(\mathrm{r}=0.661$; $\mathrm{p}=0.0001) ; \mathrm{WC}(\mathrm{r}=0.664 ; \mathrm{p}=0.0001), \mathrm{SBP}(\mathrm{r}=$ $0.607 ; \mathrm{p}=0.0001)$, and DBP $(\mathrm{r}=0.447 ; \mathrm{p}=0.0001)$ (Figure 1). Also, as illustrated by Figure 2, epicardial fat thickness showed a statistically significant positive correlation with insulin plasma levels $(\mathrm{r}=0.505 ; \mathrm{p}=$ $0.0001), \mathrm{Tg} / \mathrm{HDL}-\mathrm{C}$ ratio $(\mathrm{r}=0.447 ; \mathrm{p}=0.0001)$, and non-HDL-C $(\mathrm{r}=0.353 ; \mathrm{p}=0.007)$; and a statistically significant negative correlation with plasma concentrations of adiponectin $(\mathrm{r}=0.499 ; \mathrm{p}=0.0001)$. There was no correlation between hs-CRP and EAT thickness. Figure 3 also demonstrates that EAT thickness showed a statistically significant correlation with both LVM ( $\mathrm{r}$ $=0.469 ; \mathrm{p}=0.0001)$ and $\operatorname{LAV}(\mathrm{r}=0.432 ; \mathrm{p}=0.001)$.

A linear regression analysis was conducted to determine the variables that exerted the most influence on EAT thickness as a dependent variable. The univariate linear regression analysis yielded significance for SBP, insulin, Tg/HDL-C, non-HDL-C, LAV, WC, adiponectin, and LVM (Table 4). The multivariate linear regression analysis excluded BMI and DBP because of collinearity with WC and SBP, respectively, and showed that SBP, insulin, $\mathrm{Tg} / \mathrm{HDL}-\mathrm{C}$ ratio, non-HDL-C, and
LAV lost their statistical significance, whereas WC $(\mathrm{p}=$ $0.001)$, adiponectin plasma concentration $(\mathrm{p}=0.002)$, and LVM $(\mathrm{p}=0.001)$ kept theirs. All three remained as the variables that exerted the greatest effect on epicardial fat thickness, with $\mathrm{R}$ squared of 0.587 .

Logistic regression analyses were conducted using the presence of metabolic syndrome as the dependent, binary variable, and epicardial fat and adiponectin as independent variables in order to establish which of them best fitted the metabolic syndrome model in the study. The univariate analysis found that both adiponectin and epicardial fat thickness were significant $(\mathrm{p}=0.0001)$. The multivariate analysis revealed that adiponectin lost its statistical significance, whereas epicardial fat kept it $(\mathrm{p}=0.0001)$, the latter remaining as the rationale for metabolic syndrome, with R squared of 0.760 and odds ratio of 10.203 (Table 5).

Univariate and multivariate regression analyses with SBP, Tg/HDL-C ratio, non-HDL-C, and adiponectin plasma concentration as dependent variables, and BMI and EAT thickness as independent ones (Table 6) were conducted in order to assess if the relation between epicardial fat and these variables was independent of BMI. The table shows that both BMI and epicardial fat thickness bear independently on SBP; however, epicardial fat
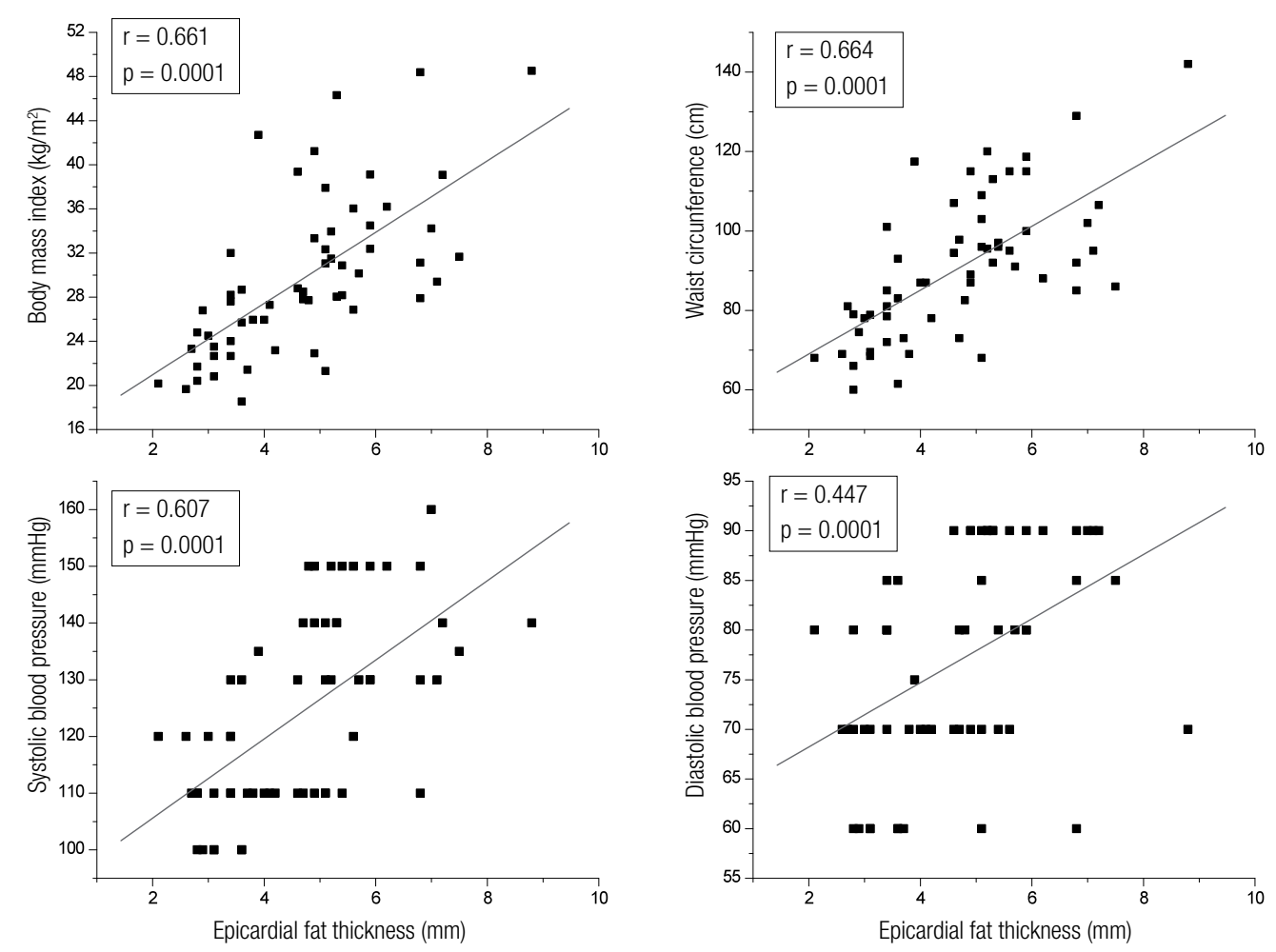

Figure 1. Epicardial fat thickness correlation with body mass index, waist circumference, systolic blood pressure, and diastolic blood pressure. 
thickness does not correlate independently with either $\mathrm{Tg} / \mathrm{HDL}-\mathrm{C}$ ratio or non-HDL-C. It is worth noting that when the plasma concentration of adiponectin was evaluated as a dependent variable, the univariate analy- sis yielded a significant inverse relation for both BMI and EAT, but BMI lost its statistical significance in the multivariate analysis, whereas epicardial fat thickness continued to maintain it $(\mathrm{p}=0.025)$.
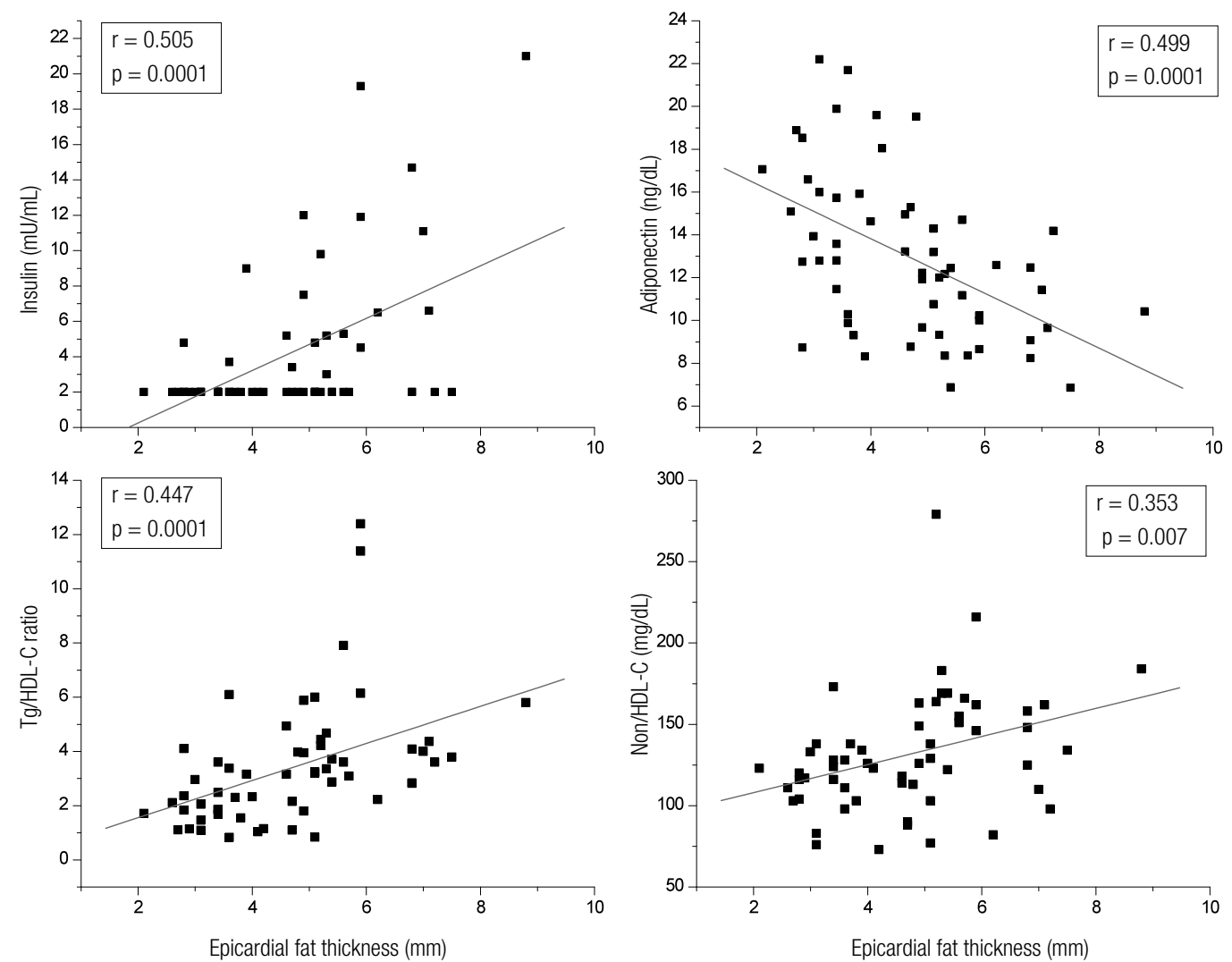

Figure 2. Epicardial fat thickness correlation with insulin, adiponectin, TG/HDL-C ratio, and non-HDL-C.
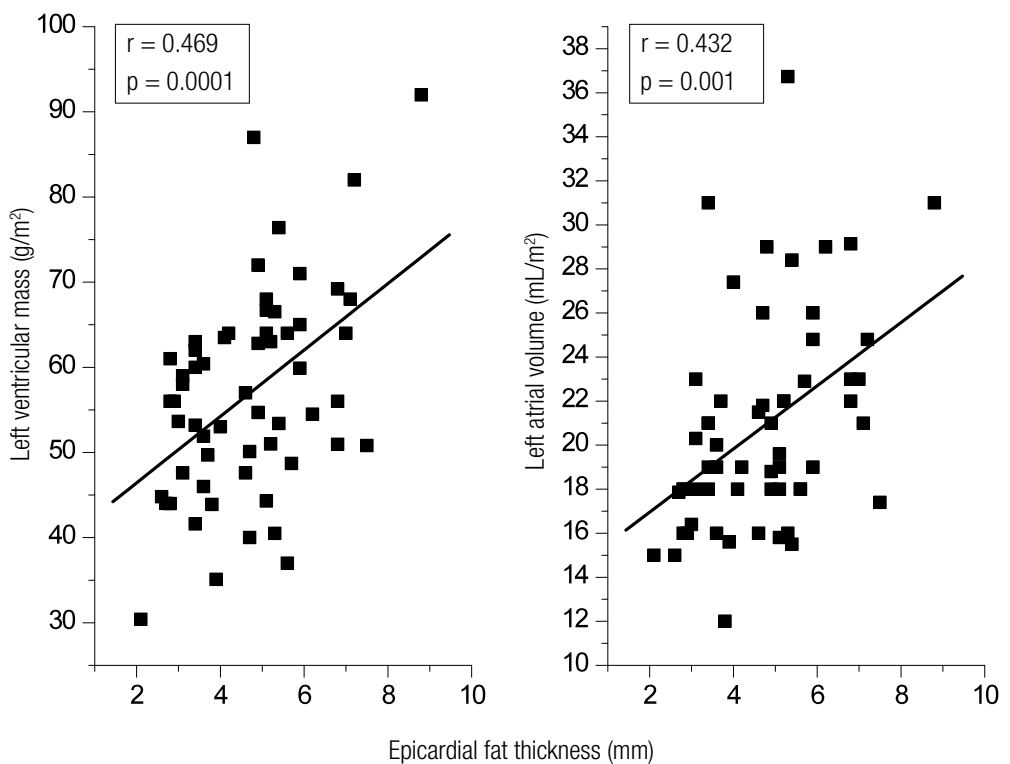

Figure 3. Epicardial fat thickness correlation with left ventricular mass, and left atrial volume. 
Table 4. Univariate and multivariate linear regression analysis with epicardial fat thickness as the dependent variable

\begin{tabular}{|c|c|c|c|}
\hline Independent variables & $\begin{array}{l}\text { Univariate } \\
\text { p value }\end{array}$ & $\begin{array}{l}\text { Multivariate } \\
\text { p value }\end{array}$ & \\
\hline Systolic blood pressure $(\mathrm{mmHg})$ & 0.0001 & 0.071 & \\
\hline Insulin (mU/mL) & 0.0001 & 0.764 & \\
\hline Tg/HDL-C ratio & 0.0001 & 0.818 & \\
\hline Non-HDL-C (mg/dL) & 0.007 & 0.994 & \\
\hline Left atrial volumen (mL/m²) & 0.001 & 0.583 & \\
\hline Waist circumference (cm) & 0.0001 & 0.001 & $\begin{array}{c}R^{2}=0.587 \\
\text { Coef. } B=0.032 \\
\text { Cl: } 0.014-0.050\end{array}$ \\
\hline Adiponectin (ng/mL) & 0.0001 & 0.002 & $\begin{array}{c}\text { Coef. } B=-0.128 \\
\text { Cl: }-0.209--0.048\end{array}$ \\
\hline Left ventricular mass ( $\left.\mathrm{g} / \mathrm{m}^{2}\right)$ & 0.0001 & 0.001 & $\begin{array}{c}\text { Coef. } B=0.042 \\
\text { Cl: } 0.019-0.065\end{array}$ \\
\hline
\end{tabular}

Table 5. Logistic regression analysis using metabolic syndrome as the dependent variable, and epicardial fat thickness and adiponectin as independent variables

\begin{tabular}{lccc}
\hline Independent variables & $\begin{array}{c}\text { Univariate } \\
\text { p value }\end{array}$ & $\begin{array}{c}\text { Multivariate } \\
\text { p value }\end{array}$ \\
\hline Adiponectin $(\mathrm{ng} / \mathrm{mL})$ & 0.0001 & 0.202 & $\mathrm{R}^{2}=0.760$ \\
Epicardial fat $(\mathrm{mm})$ & 0.0001 & 0.0001 & 0 dds ratio $=10.203$ \\
& & & $\mathrm{Cl}: 2.971-35.042$ \\
\hline
\end{tabular}

Table 6. Univariate and multivariate linear regression analysis with systolic blood pressure, $\mathrm{Tg} / \mathrm{HDL}-\mathrm{C}$ ratio, non-HDL-C, and adiponectin as dependent variables, and body mass index, and epicardial fat thickness as independent variables

\begin{tabular}{|c|c|c|c|}
\hline & $\begin{array}{c}\text { Univariate } \\
\text { p value }\end{array}$ & $\begin{array}{l}\text { Multivariate } \\
\text { p value }\end{array}$ & \\
\hline \multicolumn{4}{|l|}{ Variable dependent: } \\
\hline Independent variables: & & & $R^{2}=0.448$ \\
\hline Body mass index $\left(\mathrm{kg} / \mathrm{m}^{2}\right)$ & 0.0001 & 0.007 (IC: 0.256-1.511) & Coef. B: 0.884 \\
\hline Epicardial fat thickness (mm) & 0.0001 & 0.010 (IC: 1.044-7.181) & Coef. B: 4.113 \\
\hline \multicolumn{4}{|l|}{$\begin{array}{l}\text { Variable dependent: } \\
\text { Tg/HDL-C ratio }\end{array}$} \\
\hline Independent variables: & & & $R^{2}: 0.237$ \\
\hline Body mass index $\left(\mathrm{kg} / \mathrm{m}^{2}\right)$ & 0.001 & 0.107 (IC: -0.018-0.179) & Coef. B: 0.080 \\
\hline Epicardial fat thickness (mm) & 0.0001 & 0.082 (IC: -0.056-0.905) & Coef. B: 0.425 \\
\hline \multicolumn{4}{|l|}{$\begin{array}{l}\text { Variable dependent: } \\
\text { Non-HDL-C }\end{array}$} \\
\hline Independent variables: & & & $R^{2}: 0.140$ \\
\hline Body mass index $\left(\mathrm{kg} / \mathrm{m}^{2}\right)$ & 0.012 & 0.318 (IC: -0.831-2.509) & Coef. B: 0.839 \\
\hline Epicardial fat thickness (mm) & 0.007 & 0.152 (IC: $-2.250-14.075)$ & Coef. B: 5.913 \\
\hline \multicolumn{4}{|l|}{$\begin{array}{l}\text { Variable dependent: } \\
\text { Adiponectin }\end{array}$} \\
\hline Independent variables: & & & $R^{2}: 0.277$ \\
\hline Body mass index $\left(\mathrm{kg} / \mathrm{m}^{2}\right)$ & 0.0001 & 0.151 (IC: -0.277-0.044) & Coef. B: -0.116 \\
\hline Epicardial fat thickness (mm) & 0.007 & 0.025 (IC: -1.685-0.119) & Coef. B: -0.902 \\
\hline
\end{tabular}




\section{DISCUSSION}

Our results correspond to those of other studies, which show echocardiographically-measured EAT values linked to anthropometric and clinical metabolic syndrome components $(6,8)$. In fact, some EAT thickness values were found to have a greater significance in the metabolic syndrome group than in the control group $(5.69 \pm 1.12 v s .3 .52 \pm 0.80 ; \mathrm{p}=0.0001)$ as well as a significant correlation with BMI and WC, suggestive of obesity as a predisposing factor for epicardial fat. In fact, a recent meta-analysis evaluating the relationship between epicardial fat, indices of obesity and metabolic syndrome demonstrated that EAT thickness significantly correlated independently with each of the components of metabolic syndrome (SBP, HDL-C, fasting glucose), but the magnitude of this relationship was considerably and significantly lower than that between epicardial fat and BMI (12).

This study showed that EAT thickness exerts an influence on systolic blood pressure independently of BMI. This finding might be explained in terms of the physiopathological mechanism of insulin resistance. It has been reported, in animal models, that the release rate of fatty acids by the epicardial adipocyte is twice that of perirenal fat. This suggests a high lipolytic activity due, perhaps, to both the reduced antilipolytic effect of insulin on this tissue and the increased expression of $\beta$-adrenergic receptors, especially $\beta-3$ receptors. The $\beta-3$ receptors stimulation activates lipolysis and increases the release of free fatty acids capable of promoting arterial hypertension by means of different pathways, such as adrenergic stimulation, increase in oxidative stress, endothelial dysfunction, or vascular cell growth $(13,14)$. This theory is supported in our study by the significant correlation between epicardial fat thickness and insulin plasma concentration in the individuals studied. Furthermore, the epicardial adipocyte produces angiotensinogen, which is converted into angiotensin I and subsequently into angiotensin II, a potent vasoconstrictor and hydro-saline retention promoter (15). Interestingly, Dicker and cols. (16) demonstrated, in a sample of 127 non-obese subjects, that EAT thickness $\geq 2.4 \mathrm{~mm}$ is associated with an increased risk of high blood pressure (odds ratio 1.39; 95\% CI: 1.033-1.992).

The Tg/HDL-C ratio, frequently elevated in metabolic syndrome patients, is linked to a predominance of small and dense lipoprotein particles ( $\beta$ LDL) that result from insulin resistance, high triglyceride concentration, and low levels of HDL-C. This is the reason why this index has been proposed as a useful instrument to predict endothelial dysfunction and adverse cardiovascular events, especially in patients with a $\mathrm{Tg} /$ HDL-C ratio $\geq 3.5$ (17). In our study, the $\mathrm{Tg} / \mathrm{HDL}-\mathrm{C}$ ratio showed elevated values in the metabolic syndrome group $(4.52 \pm 2.37$ vs. $2.10 \pm 1.15 ; \mathrm{p}=0.0001)$ and a positive correlation with epicardial fat $(\mathrm{r}=0.447$; $\mathrm{p}$ $=0.0001)$. Aydin and cols. (7) found EAT thickness to be an independent factor exerting an effect on the endothelial function of metabolic syndrome patients. Our study, however, evinced no independent relationship between EAT thickness and $\mathrm{Tg}$ /HDL-C ratio.

Several studies have established the clinical importance of Non-HDL-C as a predictor of coronary artery disease and cardiovascular morbidity and mortality in patients with metabolic syndrome (18). This study found plasma concentrations of non-HDL-C significantly higher than those of the control group ( $143.84 \pm$ 41.07 vs. $116.55 \pm 21.57 ; \mathrm{p}=0.002)$, and a significant correlation between EAT thickness and Non-HDL-C $(\mathrm{r}=0.353 ; \mathrm{p}=0.007)$. Rego and cols. (19) demonstrated a significant increase of the ApoB/ApoAl ratio in subjects with an EAT thickness $\geq 5.2 \mathrm{~mm}$ compared with subjects with thickness $<5.2 \mathrm{~mm}$ (50.9 vs. $23.1 \%$; $\mathrm{p}=0.002)$. Nonetheless, similar to the Tg/HDL-C ratio, our study did not evince any independent relationship between EAT thickness and Non-HDL-C.

As for the hs-CRP, significantly higher concentrations $(6.59 \pm 6.26$ vs. $2.20 \pm 2.54 ; \mathrm{p}=0.0001)$ were observed in the MS group. This study did not find a correlation between hs-CRP and epicardial fat thickness $(\mathrm{r}=0.252 ; \mathrm{p}=0.056)$, akin to values reported in a previous study (6); on the contrary, Aydin and cols. (7) showed a strong correlation between these variables $(\mathrm{r}=0.62 ; \mathrm{p}<0.0001)$ in MS patients. The reason for these differences might involve the fact that the subject group studied by Aydin and cols. was older (52.00 \pm 7.00 years) compared with the control and metabolic subjects assessed in our study $(38.67 \pm 9.80$ and 39.06 \pm 10.00 years old, respectively), which affects the degree of vascular dysfunction and possibly the relationship between the variables.

This, as well as a former study, demonstrated that EAT thickness augmentation correlates significantly with LAV (20). Atrial distension is commonly found in obese and metabolic syndrome patients. Possibly due to the close anatomical proximity of the left atrium and 
left ventricle, an increase in EAT might mechanically affect the diastolic filling of the latter, and thus induce left atrial distension, a potential risk factor for atrial fibrillation $(20,21)$.

The strong correlation between LVM and EAT thickness has been characterized by other authors $(8,22,23)$. Several mechanisms might explain this relationship: a) EAT augmentation is associated with higher intramyocardial lipid content, and hence, with myocardial steatosis and lipotoxicity, which might induce adverse structural and functional adaptations, including cardiomyopathy (24); b) EAT may affect cardiac morphology by means of the effect, both local and systemic, of the adipocytokines it synthesizes, as some of them are capable of inducing cardiac remodeling (25); c) EAT could induce systemic insulin resistance, which in turn can promote left ventricular hyperthrophy via direct mitogenic action of insulin post-receptor pathway in myocardial cells $(2,26)$.

Our study found an inversely proportional relationship between EAT thickness and adiponectin plasma concentration, independent of BMI. Bambace and cols. (27) demonstrated that the increase in diameter of the epicardial adipocyte is associated with a decreased EAT adiponectin expression in subjects with metabolic syndrome compared with subjects without it. Interestingly, intracoronary adiponectin levels reflect the systemic concentration of this hormone, and EAT contributes, in part, to such plasma levels (28). Indeed, reduced EAT adiponectin expression in patients with ischemic cardiopathy, coupled with a significant inverse association between epicardial adiponectin expression and the extent of coronary disease, suggests that a lower production of epicardial fat adiponectin might play a relevant role in the development and severity of coronary artery disease $(29,30)$.

Furthermore, the logistic regression analysis with metabolic syndrome as a dependent variable showed that EAT thickness, rather than adiponectin, correlated better with it, a correlation that underscores the strong association between the echocardiographic evaluation of this tissue and the clinical and anthropometric components of this syndrome. Moreover, a meta-analysis using 2,027 subjects (1,030 affected) revealed that EAT mass of these patients is significantly thicker than that of controls (standardized difference in means 1.15 , 95\% CI: $0.78-1.53$; $\mathrm{p}=0.0001)(31)$. It is worth noting that while this difference is independent of both the criteria used to define metabolic syndrome and the cardiac cycle time period when EAT was measured (end-systole or end-diastole), it does vary according to ethnicity (31). In fact, this study shows that the greatest difference in EAT thickness between subjects with metabolic syndrome and those without it is observed among Caucasians, followed by Hispanics, Turks, and Asians (31). It is not clear if these differences result from racial variations in the amount of visceral adipose tissue, as has been reported in some ethnic groups (32). In our experience, significant differences have been observed in Venezuela. EAT thickness reported in the city of Ciudad Bolívar (8) was significantly greater than that found during the course of this study in Mérida, which leads us to hypothesize that sociocultural, climatic, and dietary factors exert an influence on EAT thickness and its relationship with metabolic syndrome.

\section{CONCLUSION}

A thicker epicardial adipose tissue was confirmed in metabolic syndrome patients when compared with control subjects, as well as a direct relationship between EAT and WC, blood pressure, Tg/HDL-C ratio, and plasma insulin levels. A significant inverse correlation between EAT thickness and adiponectin plasma concentration was also observed, a link which might be useful as a biomarker for this disease.

Acknowledgments: We would like to thank Professor Carlos Mota, Dr. Gianluca Iacobellis, and Dr. Joselyn Rojas for their support and their valuable comments on the manuscript. This study was supported by a grant from the Consejo de Desarrollo Científico, Humanístico, Tecnológico y del Arte de la Universidad de Los Andes, Mérida, Venezuela, code ADG M-10.

Disclosure: no potential conflict of interest relevant to this article was reported.

\section{REFERENCES}

1. Kershaw EE, Flier J. Adipose tissue as an endocrine organ. J Clin Endocrinol Metab. 2004;89(6):2548-56.

2. Lima-Martínez MM, Blandenier C, lacobellis G. Epicardial adipose tissue: more than a simple fat deposit?. Endocrinol Nutr. 2013;60(6):320-8.

3. lacobellis G, Corradi D, Sharma AM. Epicardial adipose tissue: anatomical, biomolecular and clinical relation to the heart. Nat Cardiovasc Clin Pract Med. 2005;2(10):536-43.

4. Chandran M, Phillips SA, Ciaraldi T, Henry RR. Adiponectin: more than just another fat cell hormone?. Diabetes Care. 2003;26(8):2442-50.

5. Ouchi N, Kihara S, Funahashi T, Nakamura T, Nishida M, Kumada $M$, et al. Reciprocal association of C-reactive protein with adiponectin in blood stream and adipose tissue. Circulation. 2003;107(5):671-4. 
6. lacobellis G, Ribaudo MC, Assael F, Vecci E, Tiberti C, Zappaterreno $A$, et al. Echocardiographic epicardial adipose tissue is related to anthropometric and clinical parameters of metabolic syndrome: a new indicator of cardiovascular risk. J Clin Endocrinol Metab. 2003;88(11):5163-8.

7. Aydin H, Toprak A, Deyneli O, Yacizi D, Tarçin O, Sancak S, et al. Epicardial fat tissue thickness correlates with endothelial dysfunction and other cardiovascular risk factors in patients with metabolic syndrome. Metab Syndr Relat Disord. 2010;8(3):229-34.

8. Torres C, Lima-Martínez MM, Rosa FJ, Guerra E, Paoli M, lacobellis $\mathrm{G}$, et al. Epicardial adipose tissue and its association to plasma adrenomedullin levels in patients with metabolic syndrome. Endocrinol Nutr. 2011;58(8):401-8.

9. Alberti KG, Eckel RH, Grundy SM, Zimmet PZ, Cleeman JI, Donato $K A$, et al. Harmonizing the metabolic syndrome: a Joint Interim Statement of the International Diabetes Federation Task Force on Epidemiology and Prevention; National Heart, Lung, and Blood Institute; American Heart Association; World Heart Federation; International Atherosclerosis Society; and International Association for the Study of Obesity. Circulation. 2009;120(16):1640-5.

10. lacobellis G, Willens HJ. Echocardiographic epicardial fat: a review of research and clinical applications. J Am Soc Echocardiogr. 2009;22(12):1311-9.

11. Devereux RB, Alonso DR, Lutas EM, Gottlieb GJ, Campo E, Sachs I, et al. Echocardiographic assessment of left ventricular hypertrophy: comparison to necropsy findings. Am J Cardiol. 1986;57(6):450-8.

12. Rabkin SW. The relationship between epicardial fat and indices of obesity and the metabolic syndrome: a systematic review and meta-analysis. Metab Syndr Relat Disord. 2014;12(1):31-42.

13. Marchington JM, Pond CM. Site-specific properties of pericardial and epicardial adipose tissue: the effects of insulin and high-fat feeding on lipogenesis and the incorporation of fatty acids in vitro. Int J Obesity. 1990;14(12):1013-22.

14. Zhou J, Qin G. Adipocyte dysfunction and hypertension. Am J Cardiovasc Dis. 2012;2(2):143-9.

15. RoubícekT, Dolinková M, Bláha J, Haluzíková D, Bosanská L, Mráz $M$, et al. Increased angiotensinogen production in epicardial adipose tissue during cardiac surgery: possible role in a postoperative insulin resistance. Physiol Res. 2008;57(6):911-7.

16. Dicker D, Atar E, Kornowski R, Bachar GN. Increased epicardial adipose tissue thickness as a predictor for hypertension: a cross-sectional observational study. J Clin Hypertens (Greenwich). 2013;15(12):893-8.

17. Cordero $A$, Andrés $E$, Ordoñez $B$, León $M$, Laclaustra $M$, Grima $A$, et al. Usefulness of triglycerides-to-high-density lipoprotein cholesterol ratio for predicting the first coronary event in men. Am J Cardiol. 2009;104(10):1393-7.

18. Contreras F, Lares M, Castro J, Velasco M, Rojas J, Guerra X, et al. Determination of non-HDL cholesterol in diabetic and hypertensive patients. Am JTher. 2010;17(3):337-40.

19. Rego JO, lacobellis G, Sarmientos JC, Mustelier JV, Aquiles EW, Rodríguez VM, et al. Epicardial fat thickness correlates with ApoB/
ApoA1 ratio, coronary calcium and carotid intima media thickness in asymptomatic subjects. Int J Cardiol. 2011;151(2):234-6.

20. lacobellis G, Leonetti F, Singh N, Sharma AM. Relationship of epicardial adipose tissue with atrial dimensions and diastolic function in morbidly obese subjects. Int J Cardiol. 2007;115(2):272-3.

21. lacobellis G. Is obesity a risk factor for atrial fibrillation?. Nat Cardiovasc Clin Pract Med. 2005;2(3):134-5.

22. Corradi D, Maestri R, Callegari S, Pastori P, Goldoni M, Luong TV, et al. The ventricular epicardial fat is related to the myocardial mass in normal, ischemic and hypertrophic hearts. Cardiovasc Pathol. 2004;13(6):313-6.

23. lacobellis G, Ribaudo MC, Zappaterreno A, lannucci CV, Leonetti F. Relation between epicardial adipose tissue and left ventricular mass. Am J Cardiol. 2004;94(8):1084-7.

24. Kankaanpaa M, Lehto HR, Parkka JP, Komu M, Viljanen A, Ferrannini $E$, et al. Myocardial triglyceride content and epicardial fat mass in human obesity: relationship to left ventricular function and serum free fatty acid levels. J Clin Endocrinol Metab. 2006;91(11):4689-95.

25. lacobellis G, Bianco AC. Epicardial adipose tissue: emerging physiological, pathophysiological and clinical features. Trends Endocrinol Metab. 2011;22(11):450-7.

26. Lima-Martínez MM, Aguirre M, Rojas J, Paoli M, lacobellis G. Cardiac adiposity: epicardial and pericardial fat, atherosclerosis, insulin resistance, and other partners in crime. In: Lopez Garcia CM, Perez Gonzalez PA, editors. Handbook on metabolic syndrome: classification, risk factors and health impact. 1st ed. New York: Nova Science Publishers; 2012. p. 145-67.

27. Bambace C, Telesca M, Zoico E, Sepe A, Olioso D, Rossi A, et al. Adiponectin gene expression and adipocyte diameter: a comparison between epicardial and subcutaneous adipose tissue in men. Cardiovasc Pathol. 2011;20(5):e153-6.

28. lacobellis G, di Gioia CR, Cotesta D, Petramala L, Travaglini C, De Santis $V$, et al. Epicardial adipose tissue adiponectin expression is related to intracoronary adiponectin levels. Horm Metab Res. 2009;41(3):227-31.

29. Eiras S, Teijeira-Fernández E, Shamagian LG, Fernández AL, Vazquez-Boquete A, Gonzalez-Juanatey JR. Extension of coronary artery disease is associated with increased IL- 6 and decreased adiponectin gene expression in epicardial adipose tissue. Cytokine. 2008;43(2):174-80.

30. Teijeira-Fernández E, Eiras S, Salgado Somoza A, Gonzalez-Juanatey JR. Baseline epicardial adipose tissue adiponectin levels predict cardiovascular outcomes: a long-term follow-up study. Cytokine. 2012;60(3):674-80.

31. Pierdomenico SD, Pierdomenico AM, Cuccurullo F, lacobellis G. Metaanalysis of the relation of echocardiographic epicardial adipose tissue thickness and the metabolic syndrome. Am J Cardiol. 2013;111(1):73-8.

32. Willens HJ, Gómez-Marín O, Chirinos JA, Goldberg R, Lowery $\mathrm{MH}$, lacobellis $\mathrm{G}$. Comparison of epícardial and pericardial fat thickness assessed by echocardiography in African American and non-Hispanic White men: a pilot study. Ethn Dis. 2008;18(3):311-6. 